\title{
Settlement success, spatial pattern and behavior of mussel larvae Mytilus spp. in experimental ‘down- welling' systems of varying velocity and turbulence
}

\author{
Fabrice Pernet ${ }^{1,4, *}$, Réjean Tremblay $^{2}$, Edwin Bourget ${ }^{1,3}$ \\ ${ }^{1}$ Québec Océan, Université Laval, Pavillon Vachon, Cité universitaire, Québec G1K 7P4, Canada \\ ${ }^{2}$ Societé de Devéloppement de l'Industrie Maricole (SODIM), 137-3 rue de la Reine, Gaspé, Québec G5X 1T5, Canada \\ ${ }^{3}$ Vice-rectorat à la recherche, Université de Sherbrooke, Pavillon central, Sherbrooke, Québec J1R 2R1, Canada \\ ${ }^{4}$ Present address: National Research Council, 1411 Oxford Street, Halifax, Nova Scotia B3H 3Z1, Canada
}

\begin{abstract}
This paper presents results of the effect of water flow in experimental 'downwelling' systems on settlement success, settler distribution and behavior of Mytilus spp. larvae. The hypothesis of active habitat selection in relation to hydrodynamics was tested by direct observation of larvae during settlement using an endoscope camera and the comparison of distribution of settled larvae with that of inert particles mimicking passive behavior. The downwelling system consisted of cylinders in which water inflow was controlled. Six water flows, from 0 to $50 \mathrm{l} \mathrm{h}^{-1}$, were used in quadruplicate. An acoustic Doppler velocimeter (ADV) was used to measure velocity fluctuations in 3 dimensions along 4 transects per experimental unit. Settlement success was positively correlated with centrifugal and advective flow velocity and turbulence measured immediately above the mesh bottom. Mussel larvae actively selected microhabitats characterized by low shear stress and high advection when water flow in the cylinders ranged from 0 to $40 \mathrm{l} \mathrm{h}^{-1}$. At higher water flow, mussel larvae were distributed similarly to passive particles and are apparently unable to overcome the flow regime, thus limiting their ability to exhibit settlement preference. In this study, total conformity between settlement and inert particle patterns was never reached, suggesting that settlement was, to a certain extent, under behavioral control.
\end{abstract}

KEY WORDS: Larvae $\cdot$ Hydrodynamic $\cdot$ Settlement $\cdot$ Distribution $\cdot$ Bivalve $\cdot$ Mussel

\section{INTRODUCTION}

The life cycle of most benthic marine invertebrates involves a planktonic phase during which dispersal occurs, and a benthic phase during which habitat quality is tested prior to settlement and juvenile development. Studies of recruitment in larvae of benthic marine animals have shown that the hydrodynamic regime is an important controlling factor (Eckman 1983, Butman 1987). At large spatial scales, transport of soft bottom planktonic larvae of a large number of species is driven by hydrodynamics, since the larvae are deposited passively to settlement sites and accumulate like inert particles (Hannan 1984, Butman 1989). The relative importance of physical and biologi- cal factors in governing settlement processes has been widely debated (Woodin 1986). The emerging consensus is that the settlement pattern is under the influence of both biological and physical processes acting at different spatial scales. The hydrodynamic regime influences the probability that a larva will encounter a suitable substrate, whereas behavioral components determine whether settlement occurs (Mullineaux \& Butman 1991, Pawlik et al. 1991, Mullineaux \& Garland 1993, Pawlik \& Butman 1993, Snelgrove 1994, Snelgrove et al. 1999, Harvey et al. 1995a, Toonen \& Pawlik 1996, 2001a,b, Harvey \& Bourget 1997, Bourget \& Harvey 1998, Eckman \& Duggins 1998, Walters et al. 1999, Wright \& Boxshall 1999, Boxshall 2000, Lindegarth et al. 2002). Final attachment of various inverte- 
brate species results from an active selection of microhabitats in relation to the boundary layer flow (shear stress) (Mullineaux \& Butman 1990, 1991, Mullineaux \& Garland 1993, Harvey \& Bourget 1997, Bourget \& Harvey 1998, Qian et al. 1999).

To investigate whether settlement involves active or passive habitat selection, indirect and direct methods of observation have been used. Indirect methods compare patterns of settlement and abundance of settled larvae between experimental and control situations, in order to determine whether the larvae have selected or rejected a particular substrate. Another approach compares the distribution of settled larvae with that of inert particles having a sinking velocity, shape and diameter comparable to larvae (Hannan 1984, Butman 1989, Pawlik et al. 1991, Harvey et al. 1995a). Finally, direct methods are observations of larval behavior during settlement. A recent approach involves video recording and image analysis of larval behavior using endoscope cameras (Walters et al. 1999). The authors document the exploration behavior of invertebrate larvae in relation to hydrodynamics. However, these approaches have not yet been used simultaneously to test the hypothesis of active or passive habitat selection.

This paper presents results of the effect of hydrodynamic characteristics of flow generated in experimental 'downwelling' systems on settlement success, settler distribution and behavior of mussel larvae Mytilus spp. In this study, we used cylinders, modified from the common model used in commercial bivalve hatcheries, to mimic the effect of a downward-oriented flow onto a mesh substratum. The relative simplicity of the flow generated by this system provides the opportunity to study larval settlement in relation to velocity and turbulence.

This study had 3 objectives: (1) to test the effect of hydrodynamics on the settlement success of Mytilus spp. larvae; (2) to examine the relationship between the settlement pattern and hydrodynamics; and (3) to determine, using both direct and indirect observation methods, whether the observed settlement pattern involved passive or active habitat selection.

\section{MATERIALS AND METHODS}

Larval culture. The relationship of water velocity and turbulence to settlement of mussel Mytilus spp. larvae was examined at the experimental hatchery of Ministère de l'Agriculture, des Pêcheries et de l'Alimentation du Québec (MAPAQ) at Grande-Rivière $\left(48^{\circ} 30^{\prime} \mathrm{N}, 65^{\circ} 15^{\prime} \mathrm{W}\right.$, Quebec, Canada). Rearing of mussel larvae is described elsewhere (Pernet et al. submitted). Briefly, adult mussels were induced to spawn by warming to $23^{\circ} \mathrm{C}$ following the method described by Qiu et al. (2002). Gametes from 5 to 10 individuals were mixed at a ratio of about 10 sperm per oocyte. The fertilized eggs were left undisturbed at $15^{\circ} \mathrm{C}$ for 8 to $12 \mathrm{~h}$. Swimming embryos were siphoned into a $10001 \mathrm{Xactic}^{\circledR}$ tank at an initial density of 1 ind. $\mathrm{ml}^{-1}$ and fed every $4 \mathrm{~d}$ during water renewal with a mixture of Isochrysis spp. (clone T-ISO) and Chaetoceros muelleri (clone CHGRA) at a ration of $1.5 \times 10^{4}$ cell ml $\mathrm{m}^{-1}$ (50:50 of each species); $23 \mathrm{~d}$ after fertilization, when eyed larvae first appeared (230 $\mu \mathrm{m}$ shell size), they were introduced into the nursery system.

Experimental conditions. Briefly, seawater (28 ppt salinity) was continuously pumped from $3 \mathrm{~m}$ depth near the station, sand-filtered, UV treated and heated to between 15 and $17^{\circ} \mathrm{C}$. The maximum water supply capacity was ca. $351 \mathrm{~min}^{-1}$. The seawater passed through a $1 \mu \mathrm{m}$ bag filter before reaching a water column whose height was controlled by an overflow pipe to avoid water flow variation in the cylinders (Fig. 1A). The seawater was distributed to two $1500 \mathrm{l}$ tanks in 4 separate branches, each connected to 6 evenly spaced PVC cylinders $(20 \mathrm{~cm}$ in diameter). Water passed through a flow meter (40 to $400 \mathrm{l} \mathrm{h}^{-1}$ ) and a valve for gross adjustment before being diverted toward 2 cylinders (Fig. 1B). Water inflow to each cylinder was adjusted using a valve and delivered by a $0.6 \mathrm{~cm}$ diameter pipe. Cylinders were made of PVC tubing (Fig. 1C). The bottom part (5 cm high) was covered by a $132 \mu \mathrm{m}$ nylon screen, which was used as the settlement substratum for the larvae. The central part consisted of a tube $20 \mathrm{~cm}$ high fitted to the bottom part. The upper part consisted of a cap fitted to the middle part, with a hole in the center to connect the water supply. The sieve was tightly fitted to a ring $1 \mathrm{~cm}$ high, glued to a PVC floor which was positioned $23 \mathrm{~cm}$ below the water surface. Circular holes $(20 \mathrm{~cm}$ in diameter) were made at the positions of the sieves in the floor to ensure that water flowed out without perturbation. The water level in each tank was kept constant using an overflow. The food algae were injected into the system via a pulse pump.

Experimental design. Treatments consisted of 6 different water flows $\left(0,10,20,30,40\right.$ and $\left.50 \mathrm{l} \mathrm{h}^{-1}\right)$ and in quadruplicate. Treatment application was randomly assigned to 2 cylinders per tank. In the zero flow treatment, larvae were maintained in the water column by injecting air bubbles at the center of the cylinder, $10 \mathrm{~cm}$ above the screen.

The water flow characteristics were determined using a $10 \mathrm{MHz}$ acoustic Doppler velocimeter probe $\left(\mathrm{ADV}\right.$, Sontek $\left.{ }^{\circledR}\right)$. The ADV probe components consisted of an acoustic transmitter and 3 acoustic receivers measuring water velocity in the $x^{-}, y^{-}$and $z-$ axes with accuracy in the range of 0.1 to $300 \mathrm{~cm} \mathrm{~s}^{-1}$. 
A
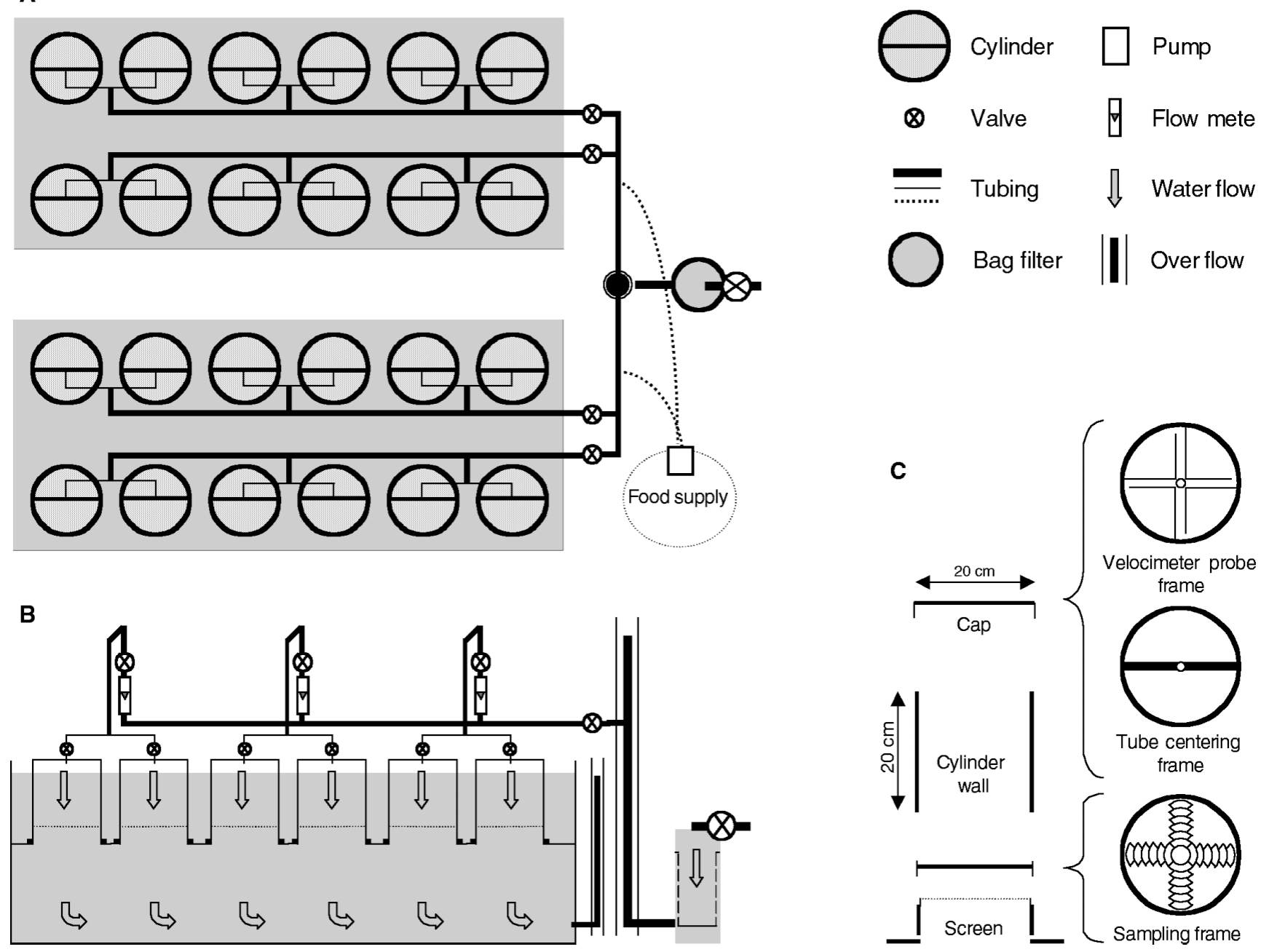

Fig. 1. (A) Above view of the experimental nursery system, (B) lateral view of 6 experimental units, (C) a sieve and its components

The screen was defined as representing the $x$ - and $y$ axes. The $x$-axis corresponded to the centripetal $(+)$ or centrifugal (-) components of the flow, whereas the $y$-axis represented the clockwise (+) or counterclockwise (-) orientations. The $z$-axis was normal (perpendicular) to the screen (advection), i.e. upward (+) or downward $(-)$ oriented (Fig. 1C). Total velocity $\left(\mathrm{V}_{\Sigma}\right)$ was obtained by calculating the square root of the sum of the squared $x^{-}, y^{-}$and $z$ spatial components (termed respectively $u, v$ and $w$ ). The ADV was set to sample at $\pm 10 \mathrm{~cm} \mathrm{~s}^{-1}$ velocity range, $25 \mathrm{~Hz}$ frequency for $3 \mathrm{~min}$. Turbulence fluctuations in the $x^{-}(\Delta u), y-(\Delta v)$ and $z-(\Delta w)$ axes and total $\left(\Delta \mathrm{V}_{\Sigma}\right)$ were defined as the SD of $u, v, w$ and $V_{\Sigma}$ respectively within the $3 \mathrm{~min} A \mathrm{ADV}$ sampling period. Velocity measurements were carried out $1 \mathrm{~mm}$ above the bottom screen. The volume sampled was cylindrically shaped, approximately $6 \mathrm{~mm}$ in diameter and $9 \mathrm{~mm}$ high (ca. $0.3 \mathrm{~cm}^{3}$ ). This volume was located $5 \mathrm{~cm}$ from the acoustic transmitter. Hydrodynamic data were extracted from 24 sub-areas per screen divided in 4 radial transects (6 cells evenly spaced at $1 \mathrm{~cm}$ intervals per transect, Fig. 1C, Table 1). The transects were north, south, east and west oriented. To operate hydrodynamic mapping with accuracy, the ADV was clamped on a manipulator arm and the stem of the probe was inserted in the slots of the graduated cap of the cylinders (Fig. 1C). The characterization of the center and the edge of the screen was not possible due to the water supply tube and sieve wall respectively. Therefore, the study area was limited to an $8 \mathrm{~cm}$ radius disk without the center $(2 \mathrm{~cm}$ radius). Velocity was considered null in the zero flow treatment, because recorded values were below the $0.1 \mathrm{~cm} \mathrm{~s}^{-1}$ detection threshold of the ADV. During ADV measurements, the signal to noise ratio was 30 to $40 \%$ and correlation data were 90 to $100 \%$ which is a desired value for good velocity data. To provide scattering material, $10 \mu \mathrm{m}$ diameter hollow glass spheres (available from Sontek ${ }^{\circledR}$ ) were added to the cylinders during the ADV measurement. 
Table 1. Generalized, randomized split-split plot design for sampling hydrodynamics and spatial distribution of larvae and inert particles in cylindrical experimental units

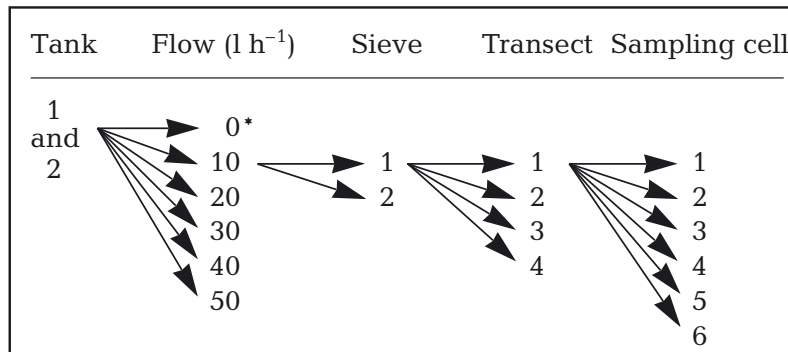

*Velocity was considered 0 in the no flow condition and hydrodynamic mapping was not done

With a plastic pipette, 3000 competent larvae per cylinder $\left(0.75\right.$ larvae $\mathrm{ml}^{-1}$ or 7.5 larvae $\mathrm{cm}^{-2}$ ) were introduced at the end of the water supply tube. Mussels were considered competent when at least $50 \%$ of the larvae exhibited an eye-spot or pedal exploration. The experiment was run for $7 \mathrm{~d}$, after which the water supply was turned off and the cylinders were taken out of the tank. The screen was carefully separated from the cylinder wall and gently rinsed in seawater to remove unattached larvae. Unattached larvae were counted and considered as swimmers. Attached larvae were considered to have settled. Larvae did not settle on the walls of the sieves. The spatial distribution of settlers on the study area was determined by fitting a frame to the screen (Fig. 1C). The sampling frame consisted of a transparent slide of 24 sub-areas along the 4 radial transects previously described. The sampling cell had a circular area of $4 \mathrm{~cm}^{2}$. The sampling cell width $(1 \mathrm{~cm})$ corresponded to the distance between each sampling cell. The number of settlers per cell was counted under a dissecting microscope. The screen was placed in a bleach solution $(1 \%)$ for $10 \mathrm{~min}$ to detach the settlers (Pearce \& Bourget 1996). 'Settlement success' was expressed as the total number of settlers in each experimental unit. Finally, mortality was assessed by subtracting the number of settlers and swimmers from the initial number of larvae introduced into the cylinder.

Larval behavior. Two approaches were used to determine whether the settlement pattern of Mytilus spp. involved a passive or an active process in relation to water velocity and turbulence.

(1) Behavioral observations were carried out on larvae subjected to the treatments 0,20 and $50 \mathrm{l} \mathrm{h}^{-1}$ at Days 23, 26 and 29 after fertilization. Larval behavior was examined in relation to age, because selectivity may decrease if settlement is postponed due to the lack of appropriate habitat (Pechenik et al. 1993, Qian \&
Pechenik 1998, Miron et al. 1999, Toonen \& Pawlik $2001 \mathrm{a}, \mathrm{b})$. The method used to examine larval behavior was described by Walters et al. (1999). Briefly, an Olympus K17-18-00 endoscope (1.7 mm in diameter, $186 \mathrm{~mm}$ length) and video camera were attached to a micro-manipulator arm, allowing 2-dimensional movement. The video output was sent to an $8 \mathrm{~mm}$ video recorder (Optiscan 1US-1). An Olympus $250 \mathrm{~W}$ high intensity xenon light source (Model ILV-2) provided cold light to the extremity of the endoscope. The endoscope had a large depth of field and was maintained at $2 \mathrm{~cm}$ distance from the target, thus minimizing any turbulence effects on the organism. Observations of larval behavior in each trial lasted until the larvae had stopped movement for 5 min or had moved out of the field covered by the camera $(5.5 \times 3.5 \mathrm{~cm})$. Behavioral sequences lasted an average of $6 \mathrm{~min}$ (from 1 to $33 \mathrm{~min})$.

(2) When larvae were removed from the experimental units, 3000 inert spherical PVC particles similar to Mytilus spp. larvae $(210 \mu \mathrm{m}$ mean diameter, 0.20 to $0.35 \mathrm{~cm} \mathrm{~s}^{-1}$ sinking velocity) were introduced at the end of the water supply to mimic passive larvae. The experiment lasted $24 \mathrm{~h}$ to allow particle deposition. Then, the water supply was turned off and the sieves were carefully removed from the tank. Each screen was separated from the sieve wall and the spatial pattern of particles on the sieve was examined in relation to water flow as previously described for larvae.

Statistical analysis and graphical representation. Hydrodynamic characterization of flow: A split-split plot factorial ANOVA (generalized randomized block) was used to analyze the effect of flow treatment, transect and sampling cell position on hydrodynamic variables recorded in each sampling cell. Hydrodynamic variables were total velocity $\left(\mathrm{V}_{\Sigma}\right)$ and turbulence $\left(\Delta \mathrm{V}_{\Sigma}\right)$, measured in the $x^{-}, y_{\text {- }}$ and $z$-axes, termed respectively $u, v$ and $w$ for velocity and $\Delta u, \Delta v$ and $\Delta w$ for turbulence. For each variable, spatial structure was described through structure function to quantify the spatial dependency and partition it amongst distance classes (Legendre \& Legendre 1998). Statistical models were fitted to the spatial correlogram using the Compmix macro command (SAS Institute 2000; available at http://ftp.sas.com/techsup/download/stat/compmix6. html). With the Mixed procedure, the Compmix macro command allows the fit of multiple models. The following models were tested: 'simple' which specifies a standard variance component, 'compound-symmetry' which specifies the compound-symmetry structure having a constant variance and covariance, 'linear', 'log-linear', 'power' and 'exponential'. All of these models were tested for each flow treatment. To determine the best fit function for each variable, the models were compared on the basis of the Akaike information 
criterion corrected for low n-value (AICC, the smaller is better) (see Tabachnik \& Fidell 2001, p 884). The repeated option was applied to the interaction term 'Transect $\times$ Cell' combined with the specific covariance structure of the matrix (the best fit function) to take spatial dependency into account. The variability among sieves (within flow), among transects (within sieve) and among cells (within transect) in hydrodynamic variables recorded in each sampling cell was assessed using the coefficient of variation (CV). CV quantifies how different the hydrodynamics were among and within the sieves. This parameter was evaluated because it was assumed that variation among sieves was negligible.

Influence of hydrodynamic regime on settlement: (1) ANOVA was used to determine the effect of the water flow treatment (independent variable) on percent of settlement, swimmers and mortality (dependent variables). (2) Regression models were applied to investigate the relationship between percent settlement and average velocity and turbulence measured along the $x-, y$ - and $z$-axes of the sieve. (3) The effect of hydrodynamic parameters on the spatial distribution of settlers on the screen was examined. To this purpose, we used regression models to assess the relationship between the number of settlers and the hydrodynamic variables recorded in each sampling cell for each given flow treatment. Regressions were performed using averaged data of 4 replicate sieves.

Larval behavior: We investigated whether the settlement pattern of larvae resulted from active or passive processes. Regression models were used to assess the relationship between the number of inert particles and the hydrodynamic variables recorded in each sampling cell per flow treatment. The Pearson correlation coefficient between number of settlers and inert particles was calculated for each flow treatment. The strength of the correlation gives an indication of the similarity between settler and particle distribution. Regressions were also carried out on data averaged from the 4 replicate sieves per sampling cell position. Larval behavior was categorized as follows: (1) larvae actively exploring the substrate with the foot or (2) not moving, remaining attached to the screen; and (3) actively swimming in the water column or (4) passive in the water column. Based on these observations, a time budget (relative time spent by each larva exhibiting a specific behavior) was determined. No statistical analysis was performed on these data since this experiment was not replicated.

Homoscedasticity of variances were tested by Levene's test and confirmed by graphical examination of residuals (Sherrer 1984). When necessary, data were $\log +1$ transformed to achieve homogeneity of variances. A significant threshold of 0.05 was adopted for all statis- tical tests. All statistical analyses were carried out using SAS 8.02 (SAS Institute 1999-2001; www.sas.com).

Simplified maps of velocity and turbulence measured in the $x^{-}, y^{-}$and $z$-axes, and settler and particle distribution were plotted using the software Techplot 9.0 ${ }^{\odot}$ (Amtec Engineering 1998-2001; available at http://www.amtec.com/products/tecplot/tecplot main.htm). Maps were drawn according to the inversedistance weighting interpolation procedure, using averaged data of 4 replicate sieves. Based on the results of the previous factorial ANOVA and CV analyses, averaged data appeared to give a realistic value.

\section{RESULTS}

\section{Hydrodynamic characterization of flow}

There was a clear effect of water flow on physical variables measured in the cylinders (Table 2, Fig. 2). Particularly, increasing water flow from 10 to $50 \mathrm{l} \mathrm{h}^{-1}$ led to a significant rise of mean $V_{\Sigma}$ and $\Delta V_{\Sigma}$ in sieves from 1.41 to 4.37 and 0.40 to $1.40 \mathrm{~cm} \mathrm{~s}^{-1}$, respectively (Fig. 2). Velocity and turbulence co-varied positively. The major component of $V_{\Sigma}$ was $u$, representing $91 \%$ of $V_{\Sigma}$. The flow was centrifugal, weakly clockwise and downward oriented (negative value of $u, v$ and $w$ ). The major component of $\Delta \mathrm{V}_{\Sigma}$ was $\Delta u$, closely followed by $\Delta v$ and $\Delta w$. The $\Delta v / v$ and $\Delta w / w$ ratios were respectively 8.26 and 2.23 , whereas the $\Delta u / u$ ratio was only 0.33 . These ratios indicate the relative importance of turbulence in the flow regime. Thus, the $y$ and $z$ components of the flow were much more dominated by turbulence than the $x$ component.

Velocity was influenced by the position of the sampling cell along the transect (Table 2, Fig. 3). Specifically, $u$ was lower at the center and at the edge of the cylinder, whereas $w$ was high at the center and low at the edge. Although not clearly visible on the graph, $w$ became positive at the edge of the screen for all the tested water flows, indicating the presence of a zone of upwelling. The $y$ component of the flow $(v)$ did not vary according to the sampling cell position within a transect. The flow was oriented downward at the center of the screen, oriented centrifugally along the screen and oriented upward along the sieve wall. Three-dimensional dye visualization of the flow confirmed this pattern of circulation of water in the cylinders. Turbulence was also significantly influenced by the position of the sampling cell along the transect (Table 2, Fig. 4). Turbulence measured in the $x-, y$ - and $z$-axes was higher at the center of the screen and decreased progressively toward the edge for each water flow tested (Fig. 4). The gradient of turbulence was particularly pronounced for $v$ and $w$ compared to $u$ and increased progressively with water flow. 
Table 2. Summary of the split-split plot factorial ANOVAs arranged in generalized randomized block performed on velocity and turbulence measured in the $x$ - (horizontal, centripetal-centrifugal orientation), $y$ - (horizontal, clockwise-counter-clockwise orientation) and $z$ - (vertical, upward-downward orientation) axes as a function of water flow, tank (block), sieve and transect, taking into account spatial dependence. Velocity data are $u, v$ and $w$ and turbulence data are $\Delta u, \Delta v$ and $\Delta W$ in the $x$-, $y$ - and $z$-axes respectively. Turbulence data were $(\log +1)$ transformed. Significant probabilities are in bold $(\mathrm{p}<0.05)$

\begin{tabular}{|c|c|c|c|c|c|c|c|}
\hline \multirow[t]{2}{*}{ Source of variance } & \multirow[t]{2}{*}{ df } & \multicolumn{3}{|c|}{ Velocity } & \multicolumn{3}{|c|}{ Turbulence } \\
\hline & & $u$ & $V$ & $w$ & $\Delta u$ & $\Delta v$ & $\Delta W$ \\
\hline \multicolumn{8}{|l|}{ Whole plot analysis } \\
\hline Tank & 1 & 0.157 & 0.161 & 0.589 & 0.577 & 0.307 & 0.859 \\
\hline Flow & 4 & $<0.001$ & 0.037 & $<0.001$ & $<0.001$ & $<0.001$ & $<0.001$ \\
\hline Error a & 14 & & & & & & \\
\hline \multicolumn{8}{|l|}{ Subplot analysis } \\
\hline Transect & 3 & 0.996 & $<0.001$ & 0.002 & $<0.001$ & 0.060 & 0.011 \\
\hline Flow $\times$ Transect & 12 & 0.900 & 0.211 & 0.812 & 0.087 & 0.922 & 0.938 \\
\hline Error b & 45 & & & & & & \\
\hline \multicolumn{8}{|l|}{ Sub-subplot analysis } \\
\hline Cell & 5 & $<0.001$ & 0.709 & $<0.001$ & $<0.001$ & $<0.001$ & $<0.001$ \\
\hline Flow $\times$ Cell & 20 & 0.001 & 0.999 & $<0.001$ & $<0.001$ & $<0.001$ & $<0.001$ \\
\hline Transect $\times$ Cell & 15 & 0.501 & $<0.001$ & 0.051 & 0.035 & $<0.001$ & 0.002 \\
\hline Flow $\times$ Transect $\times$ Cell & 60 & 0.050 & 0.992 & 0.879 & 0.873 & 0.918 & 0.304 \\
\hline Error c & 300 & & & & & & \\
\hline
\end{tabular}
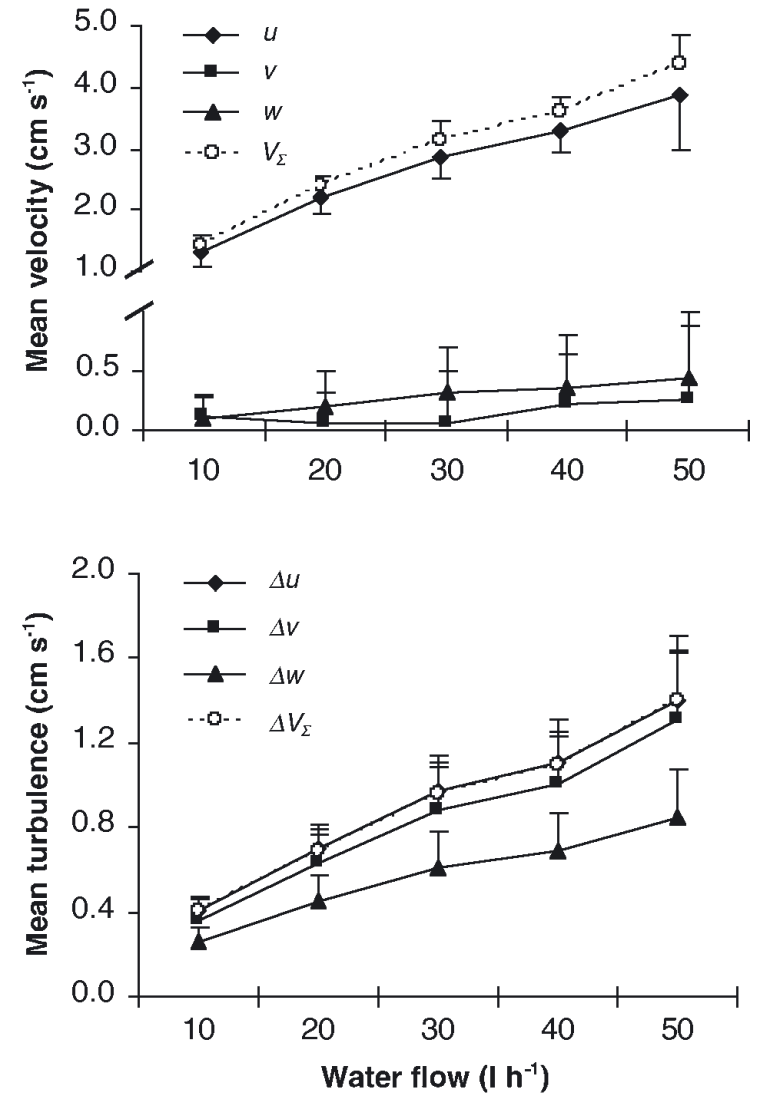

Fig. 2. Velocity and turbulence measured $1 \mathrm{~mm}$ above the screens as a function of water flow. Total velocity $\left(\mathrm{V}_{\Sigma}\right)$ and turbulence $\left(\Delta \mathrm{V}_{\Sigma}\right)$ were measured along the $x^{-}, y_{\text {- }}$ and $z$-axes. Mean $( \pm \mathrm{SD}, \mathrm{n}=4)$ of replicate sieves
Variation of hydrodynamic data among sieves within flow and among transects within a sieve were low, since most of the CVs were below $10 \%$ (Table 3). The CVs among sieves and among transects of $v$ and the $\mathrm{CV}$ among transects of $w$ were high. However, $v$ and $w$ were low ( 0.27 and $0.44 \mathrm{~cm} \mathrm{~s}^{-1}$ respectively), increasing the effect of water flow velocity variations on CVs. Besides, $v$ and $w$ constituted minor components of $V_{\Sigma}$ (Fig. 2). CVs of hydrodynamic variables among cell positions were higher than $10 \%$.

The spatial patterns of velocity and turbulence were highly correlated (Table 4 ). In fact, $u$ was highly correlated with $\Delta u$ for 30 to $50 \mathrm{l} \mathrm{h}^{-1}$ water flow treatments. Advection $(w)$ was negatively correlated with turbulence regardless of the spatial component and water flow treatment. The $x, y$ and $z$ spatial components of velocity were not significantly correlated, whereas the spatial components of turbulence were highly correlated to each other.

\section{Hydrodynamics and larval settlement}

Percent settlement increased significantly with water flow, whereas percent swimmers and mortality did not vary (Fig. 5, Table 5). Settlement success was also positively correlated with average velocity and turbulence (Fig. 6). The settlement success increased with $\Delta u, \Delta v$ and $\Delta w$, and the correlations were similar. The settlement success was also significantly correlated with centrifugal water flow velocity along the 
Flow $\left(\mathrm{lh}^{-1}\right) \quad 10$
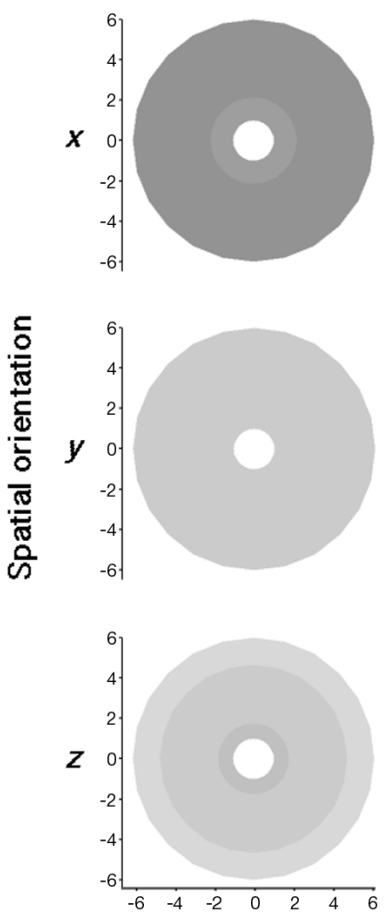

20
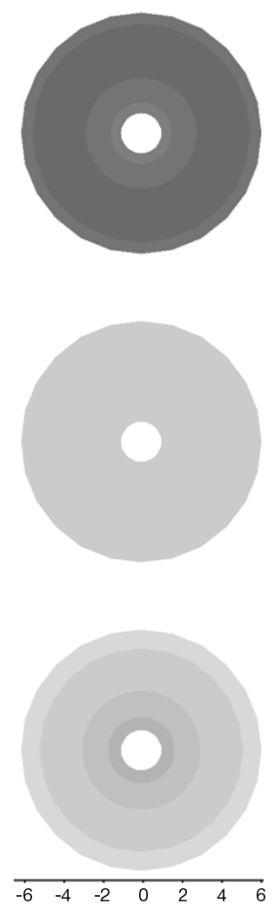

30
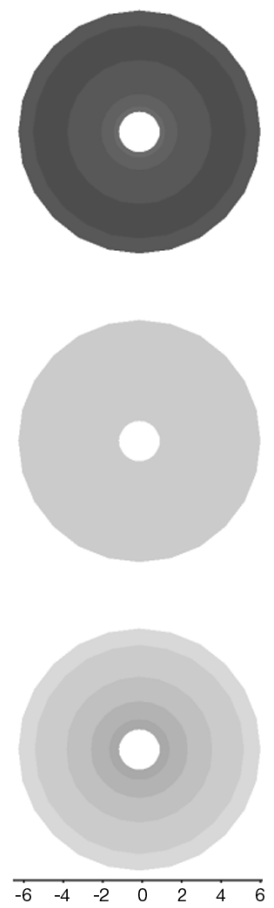

40
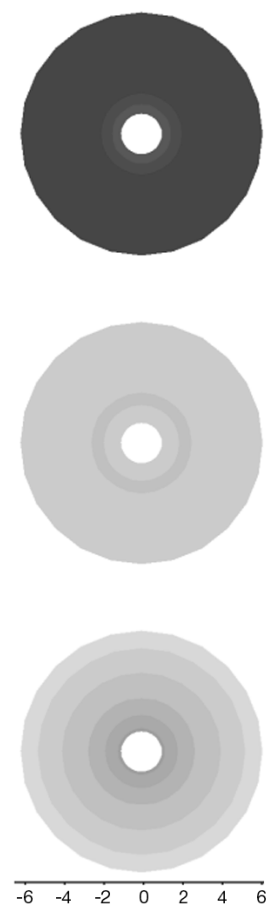

50

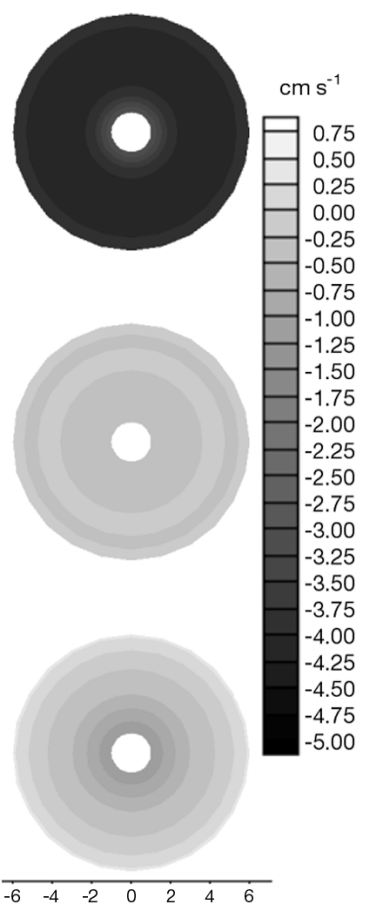

Fig. 3. Average water flow velocity along the $x^{-}, y$ - and $z$-axes, measured $1 \mathrm{~mm}$ above the screens. Scales represent coordinates where flow measurements were recorded, relative to the center of the screen $(0,0) \mathrm{in} \mathrm{cm}$. The center was not sampled

Flow $\left(\mathrm{h} \mathrm{h}^{-1}\right) 10$

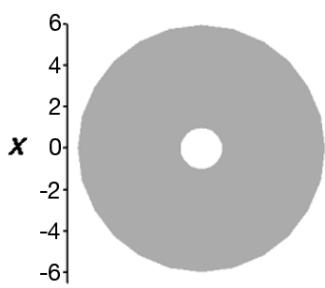

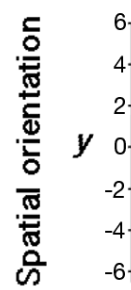

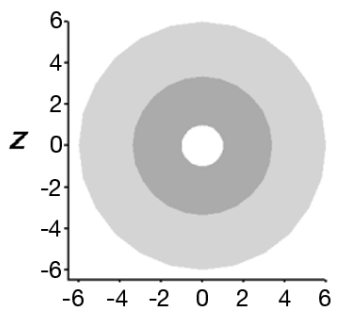

20
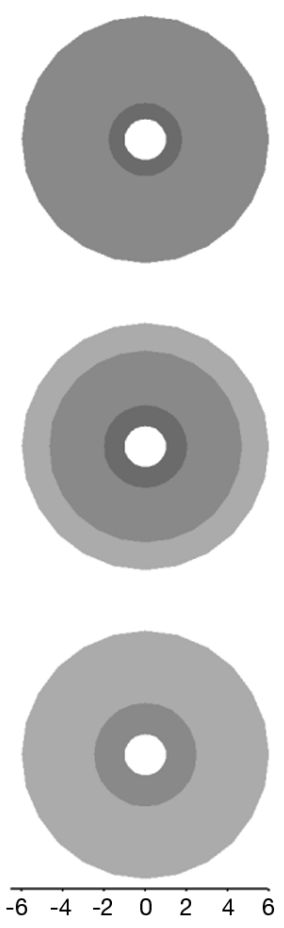

30
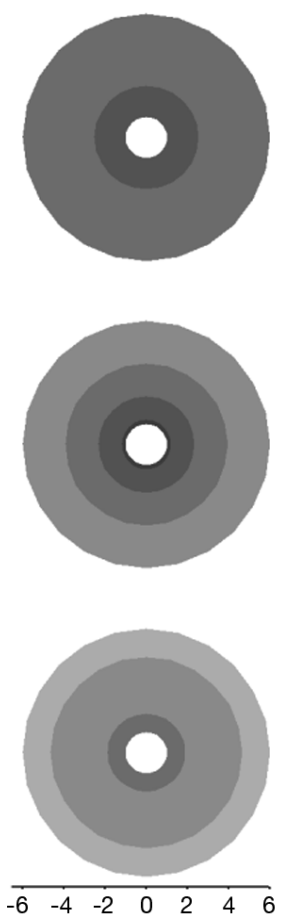

40
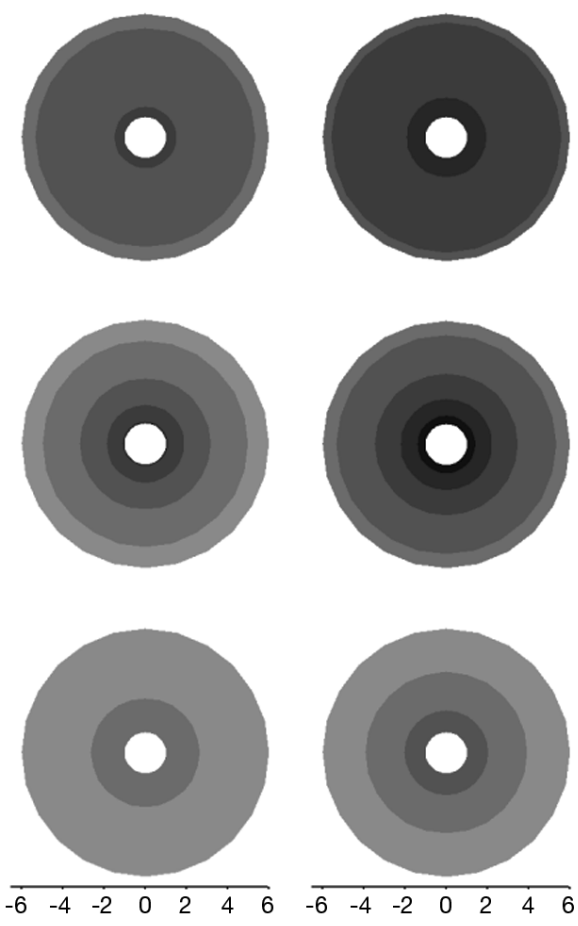

50

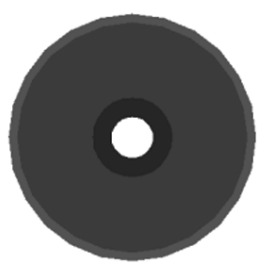

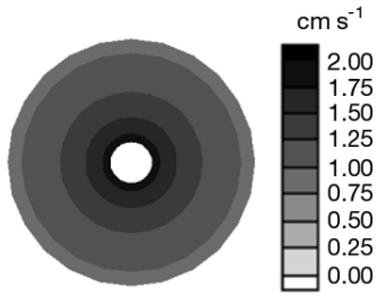

Fig. 4. Average turbulence along the $x^{-}, y^{-}$and $z$-axes. See Fig. 3 for details of measurement 
Table 3. Coefficient of variation (\%) among sieves, transects and cells calculated within flow, sieve and transect respectively performed on velocity and turbulence measured in the $x$ - (horizontal, centripetal-centrifuge orientation), $y$ - (horizontal, clockwise-counter-clockwise orientation) and $z$ - (vertical, upwarddownward orientation) axes. Velocity data are $u, v$ and $w$ and turbulence data are $\Delta u, \Delta v$ and $\Delta w$ in the $x^{-}, y^{-}$and $z$-axes respectively

\begin{tabular}{|lrrrrrrr|}
\hline \multirow{2}{*}{ Coefficient of variation (\%) } & \multicolumn{3}{c}{ Velocity } & \multicolumn{4}{c|}{ Turbulence } \\
& $u$ & $V$ & \multicolumn{1}{|c}{$w$} & $\Delta u$ & $\Delta v$ & $\Delta w$ \\
\hline Among sieves (within flow) & 8.82 & 127.94 & 14.56 & 7.88 & 8.41 & 7.74 \\
Among transects (within sieve) & 8.50 & 118.79 & 58.20 & 6.59 & 9.91 & 8.52 \\
Among cells (within transect) & 11.56 & 57.87 & 156.29 & 12.89 & 31.27 & 27.51 \\
\hline
\end{tabular}

\section{Larval behavior}

The spatial distribution of inert particles was not significantly correlated with any of the hydrodynamic variables at $10 \mathrm{l} \mathrm{h}^{-1}$ (Fig. 9). However, at 20 to $501 \mathrm{~h}^{-1}$, the number of inert particles in sampling cells was correlated with $w$ in a cubic function. In fact, the great majority of inert particles was retained in the upwelling area, close to the edge of the cylinders where $w$ values were close to 0 or positive.

screen $(u)$ and advection $(w)$. Neither survival nor swimmers were correlated with the hydrodynamic variables measured (Table 5).

Regression analysis between settlement and hydrodynamics within flow treatments revealed that the settlement pattern of mussels was influenced by different hydrodynamic variables, depending on flow treatment (Figs. 7 \& 8). For instance, there was no relationship between the number of settlers recorded in a given sampling cell and hydrodynamic variables at $10 \mathrm{l} \mathrm{h}^{-1}$ (Fig. 8). However, at $20 \mathrm{l} \mathrm{h}^{-1}$, the number of settlers per sampling cell decreased linearly with $u$, increased in a quadratic manner with $w$ and increased linearly with turbulence. At 30 and $40 \mathrm{l} \mathrm{h}^{-1}$, nearly the same relationships were observed, except that the quadratic component of the correlation between number of settlers and turbulence became more accentuated as water flow increased. Finally, at $50 \mathrm{l} \mathrm{h}^{-1}$, number of settlers was correlated only with $w$ and in a quadratic function. At 20, 30, 40 and $50 \mathrm{l} \mathrm{h}^{-1}$, the number of settlers was lowest when $w$ was 0 , and increased progressively with $w$, regardless of whether it was upward or downward oriented.

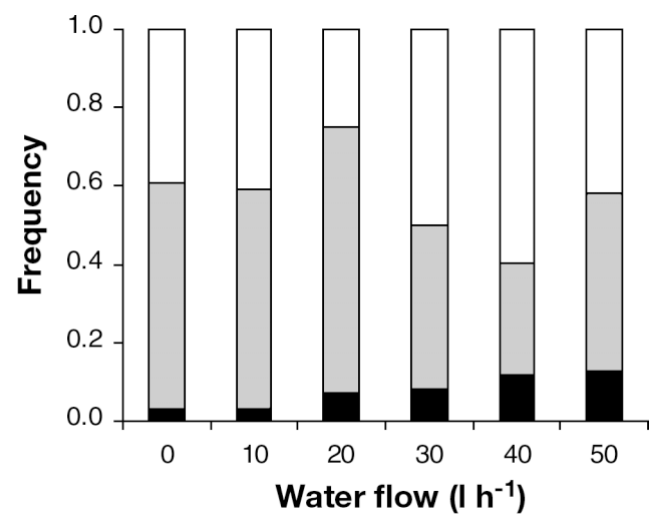

Fig. 5. Frequency (based on initial number of larvae at the beginning of the experiment) of settled (black), swimming (dotted) and dead (white) larvae in the cylindrical sieves as a function of water flow $(n=4)$
Thus, except for the $50 \mathrm{l} \mathrm{h}^{-1}$ water flow treatment, settlement of larvae and inert particle patterns were governed by different hydrodynamic variables. Regression models between number of settlers and inert particles recorded in sampling cells per flow treatment showed no relationship, except when water flow was $501 \mathrm{~h}^{-1}$ (Table 6). These results suggest an active larval behavior when explaining the settlement patterns in the 10, 20, 30 and $40 \mathrm{l} \mathrm{h}^{-1}$ cylinders. At $50 \mathrm{l} \mathrm{h}^{-1}$, the settlement pattern was better explained by passive processes $\left(r^{2}=0.67\right)$. Larval behavior videos suggest that active exploration of the settlement area at Day 23 accounted for $33 \%$ of the larval time budget at $50 \mathrm{l} \mathrm{h}^{-1}$, and represented a greater proportion of the activity than at 20 and $0 \mathrm{l} \mathrm{h}^{-1}$ (Fig. 10). Observation of larval behavior also revealed that exploration activity decreased progressively with age of larvae, except for the $50 \mathrm{l} \mathrm{h}^{-1}$ treatment, where it represented ca. $22 \%$ of the larval time budget at the end of the experiment (Day 29).

\section{DISCUSSION}

\section{Hydrodynamic characterization of flow}

We examined the effect of water flow regime on settlement of mussel larvae in an experimental downwelling system. This system generates a vortex flow of variable velocity depending on water flow $\left(0\right.$ to $\left.50 \mathrm{l} \mathrm{h}^{-1}\right)$. Traditionally, studies of hydrodynamic effects on settlement of marine invertebrates involved water flow along flat plates (Mullineaux \& Butman 1990, 1991, Pawlik et al. 1991, Mullineaux \& Garland 1993, Pawlik \& Butman 1993, Wright \& Boxshall 1999), tube pipes (Rittschof et al. 1984, Eckman \& Duggins 1998, Qian et al. 1999) and more marginally, epibenthic structures (Harvey et al. 1995a, Harvey \& Bourget 1997) or a large mesh structure (Miron et al. 1996) as a settlement substrate. In fact, hydrodynamic properties at the interface of these structures are well known (Vogel 1994) and facilitate the evaluation of velocity, turbu- 
Table 4. Correlation matrix between velocity data $u, v$ and $w$ and turbulence data $\Delta u, \Delta v$ and $\Delta w$ measured in the $X^{-}, y$ - and $z$-axes respectively, averaged by sampling cell position, according to water flow $(n=6)$. Significant probabilities are in bold $(\mathrm{p}<0.05)$

\begin{tabular}{|c|c|c|c|c|c|c|c|}
\hline \multirow{2}{*}{\multicolumn{2}{|c|}{$\begin{array}{l}\text { Flow } \\
\left(1 \mathrm{~h}^{-1}\right)\end{array}$}} & \multicolumn{3}{|c|}{ Velocity } & \multicolumn{3}{|c|}{ Turbulence } \\
\hline & & $u$ & $V$ & $w$ & $\Delta u$ & $\Delta v$ & $\Delta w$ \\
\hline \multirow[t]{6}{*}{10} & $u$ & 1.000 & & & & & \\
\hline & V & -0.538 & 1.000 & & & & \\
\hline & $w$ & -0.618 & 0.894 & 1.000 & & & \\
\hline & $\Delta u$ & 0.480 & -0.927 & -0.979 & 1.000 & & \\
\hline & $\Delta v$ & 0.727 & -0.890 & -0.987 & 0.942 & 1.000 & \\
\hline & $\Delta w$ & 0.745 & -0.885 & -0.984 & 0.935 & 0.999 & 1.000 \\
\hline \multirow[t]{6}{*}{20} & $u$ & 1.000 & & & & & \\
\hline & V & -0.426 & 1.000 & & & & \\
\hline & $w$ & -0.702 & 0.621 & 1.000 & & & \\
\hline & $\Delta u$ & 0.740 & -0.757 & -0.973 & 1.000 & & \\
\hline & $\Delta v$ & 0.802 & -0.588 & -0.977 & 0.972 & 1.000 & \\
\hline & $\Delta w$ & 0.831 & -0.568 & -0.975 & 0.963 & 0.997 & 1.000 \\
\hline \multirow[t]{6}{*}{30} & $u$ & 1.000 & & & & & \\
\hline & $V$ & 0.087 & 1.000 & & & & \\
\hline & $w$ & -0.777 & 0.180 & 1.000 & & & \\
\hline & $\Delta u$ & 0.847 & -0.205 & -0.987 & 1.000 & & \\
\hline & $\Delta v$ & 0.857 & -0.106 & -0.987 & 0.992 & 1.000 & \\
\hline & $\Delta w$ & 0.842 & -0.143 & -0.984 & 0.989 & 0.997 & 1.000 \\
\hline \multirow[t]{6}{*}{40} & $u$ & 1.000 & & & & & \\
\hline & V & 0.422 & 1.000 & & & & \\
\hline & $w$ & -0.710 & 0.301 & 1.000 & & & \\
\hline & $\Delta u$ & 0.853 & -0.062 & -0.970 & 1.000 & & \\
\hline & $\Delta v$ & 0.810 & -0.133 & -0.978 & 0.989 & 1.000 & \\
\hline & $\Delta w$ & 0.789 & -0.165 & -0.980 & 0.983 & 0.999 & 1.000 \\
\hline \multirow[t]{6}{*}{50} & $u$ & 1.000 & & & & & \\
\hline & V & 0.123 & 1.000 & & & & \\
\hline & $w$ & -0.651 & 0.330 & 1.000 & & & \\
\hline & $\Delta u$ & 0.846 & -0.167 & -0.955 & 1.000 & & \\
\hline & $\Delta v$ & 0.761 & -0.306 & -0.980 & 0.985 & 1.000 & \\
\hline & $\Delta w$ & 0.764 & -0.316 & -0.973 & 0.980 & 0.997 & 1.000 \\
\hline
\end{tabular}

Table 5. Summary of ANOVAs showing the effect of water flow $\left(0\right.$ to $\left.50 \mathrm{l} \mathrm{h}^{-1}\right)$ on total number of settling (settlement success), swimming and dead larvae of Mytilus spp. in cylindrical sieves ( $\mathrm{n}=4$ ). Tank effect (block) was insignificant and integrated to the error term. Settlement data were $(\log +1)$ transformed. Significant probabilities are in bold $(\mathrm{p}<0.05)$

\begin{tabular}{|llrrrrrr|}
\hline $\begin{array}{l}\text { Independent } \\
\text { variable }\end{array}$ & $\begin{array}{l}\text { Source of } \\
\text { variation }\end{array}$ & df & \multicolumn{2}{c}{ SS } & MS & $F$ & $\mathrm{p}$ \\
\hline Settled larvae & Flow & 5 & 7.20 & 1.44 & 3.25 & $\mathbf{0 . 0 2 9}$ \\
& Error & 18 & 7.97 & 0.44 & & \\
& Total & 23 & 15.17 & & & \\
Swimming larvae & Flow & 5 & 3480714.71 & 696142.94 & 1.82 & 0.159 \\
& Error & 18 & 6874114.25 & 381895.24 & & \\
Total & 23 & 10354828.96 & & & \\
& Flow & 5 & 2425569.21 & 485113.84 & 1.31 & 0.302 \\
& Error & 18 & 6646345.75 & 369241.43 & & \\
& Total & 23 & 9071914.96 & & & \\
\hline
\end{tabular}

lence, flow orientation and shear stress effects on settlement. However, the unidirectional steady water flow generated along flat plates and tube pipes is hardly typical of the wave-swept environment where many marine invertebrate species live. In fact, at the interface of thin flat plates or tube pipes, advection is minor (except when the leading edge of a flat plate is manipulated), whereas this component of the flow is probably essential to explain large settlement events occurring in the field (Denny 1988, p 141). Although, the downwelling system is not necessarily a good mimic of natural flow, the small-scale flow generated by the screen makes it possible to investigate the effect of a wide variety of flow orientations on settlement of marine invertebrates.

\section{Hydrodynamic effect on settlement}

Settlement success

Our experiment demonstrates a significant effect of the hydrodynamic regime on the settlement success of mussel larvae Mytilus spp. We showed that settlement success was correlated with average turbulence measured in the cylinders. The rate at which larvae successfully settle to the bed can be calculated as the product of the larval flux to the bed and the probability of settlement (Crimaldi et al. 2002). These authors showed that larval fluxes to the bed, as represented by the inverse of the mean time before a larvae makes contact with the bed, increases with turbulence. Based on this model, turbulence would increase settlement success. Turbulence also enhances contact rates between predators and prey, and therefore feeding efficiency (Rothschild \& Osborn 1988, Fréchette et al. 1989, Mackenzie \& Leggett 1991, Gallager 1993). Pediveliger larvae have a limited ability to feed on phytoplankton (Baker \& Mann 1994) and to meet the energetic requirement for metamorphosis (Holland \& Spencer 1973). Therefore, increasing the feeding efficiency might directly enhance larval physiological condition and settlement. The positive correlation between settlement success and main flow velocity $(u)$ and advection $(w)$ might also result from the enhanced contact rate of larvae with the substratum in fast flow (Mullineaux \& Butman 1991, Mullineaux \& Garland 1993, Pawlik \& Butman 1993, Harvey \& Bourget 1997, Qian et al. 1999, Crimaldi et al. 2002). 


\section{Settlement pattern}

For the $10 \mathrm{l} \mathrm{h}^{-1}$ flow treatment, the number of settlers per sampling cell was not correlated with any hydrodynamic variable, suggesting that small velocities were either not detected by the mussel larvae or if detected, did not provide adequate settling cues.

For flows ranging from 20 to $50 \mathrm{l} \mathrm{h}^{-1}$, the number of settlers was negatively correlated with the velocity of the centrifugal flow along the substratum $(u)$. Hence, it seems that larvae do not attach in microhabitats with strong shear stress. Previous studies have demonstrated that settlement patterns of a variety of invertebrate species are strongly related to the shear stress condition (Mullineaux \& Butman 1991, Mullineaux \& Garland 1993, Pawlik \& Butman 1993, Harvey \& Bourget 1997, Qian et al. 1999, Crimaldi et al. 2002). Despite the overall preference of several species for strong shear stress areas at medium $(\mathrm{cm})$ and larger scales $(>\mathrm{cm})$, the final settlement site of bivalve spat appears to result from an active selection for low shear stress microhabitats (Harvey \& Bourget 1997). The number of settlers was also positively correlated with advection $(w)$ whether the orientation was away from or toward the screen. Similarly, barnacle settlement was positively correlated with advection away or toward the plates (Mullineaux \& Butman 1991). Finally, the number of settlers was also correlated with turbulence in the $x^{-}, y^{-}$and $z$-axes. The presence of linear and quadratic relationships with water flow led to the absence of any consistent pattern. Previous studies involving barnacle species attributed the high settlement occurring at the vicinity of flow obstacles to the high turbulence characterizing these areas (Miron et al. 1996, Walters et al. 1997, Wright \& Boxshall 1999). However, Mullineaux \& Butman (1991) obtained very variable levels of correlation between settlement of barnacles and turbulence. Thus, the effect of turbulence on the settlement pattern of invertebrate species on hard substrate remains unclear. In this study, it is difficult to decipher the relative influence of $u, w$ or turbulence on settlement pattern since the number of settlers is simultaneously correlated with all of these 3 variables.

\section{Larval behavior}

The settlement patterns of mussel larvae did not conform to the pattern of inert particles for water flows ranging from 0 to $40 \mathrm{l} \mathrm{h}^{-1}$ (velocity range of 0 to $3.9 \mathrm{~cm} \mathrm{~s}^{-1}$ ). This underlines the fact that the number of larvae passively contacting the substratum was a poor predictor of the settlement pattern. In contrast, recent studies showed that passive processes were sufficient to explain the settlement patterns of invertebrate species on the wall of tube pipes (Eckman \& Duggins 1998, species: the barnacle Balanus sp., the mussel Mytilus trossulus, the polychaete Pseudochitinopoma occidentalis, the bryozoan Tubulipora sp. and the polychaete Eupolymnia heterobranchia) and on filamentous epibenthic substrata at the scale of 10 to $30 \mathrm{~cm}$ (Harvey et al. 1995a; species: the mussel Mytilus edulis, the clams Cerasto-

Fig. 6. Relationship between settled larvae (\%, based on initial number of larvae) and hydrodynamic data $\left(\mathrm{n}=24,6\right.$ Flows $\times 4$ Replicates). Total velocity $\left(\mathrm{V}_{\Sigma}\right)$ and turbulence $\left(\Delta \mathrm{V}_{\Sigma}\right)$ were measured along the $x^{-}, y^{-}$and $z$-axes. Significant regressions are in bold $(\mathrm{p}<0.05)$ 
Flow $\left(\mathbf{l} \mathbf{h}^{-1}\right) \quad 0$
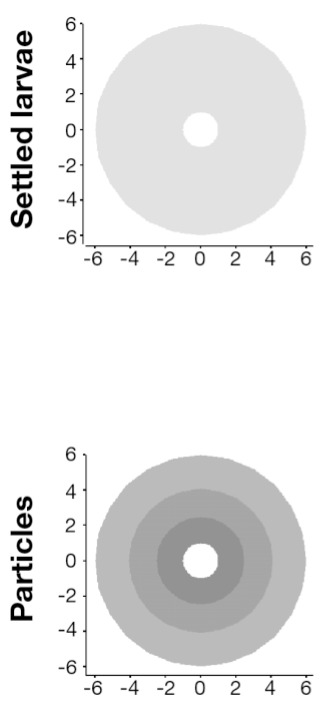

10
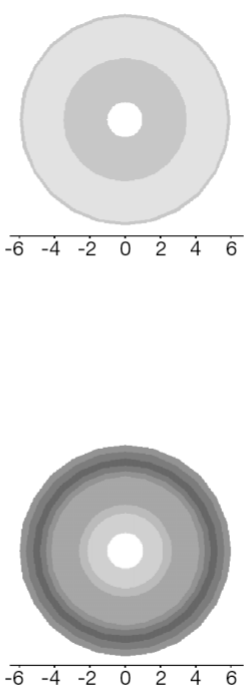

20
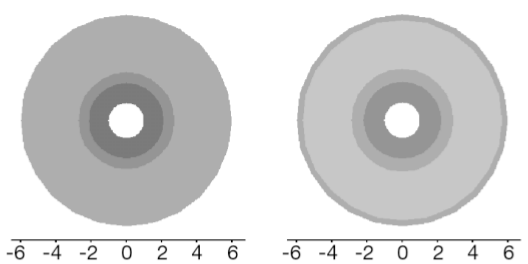

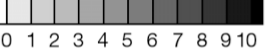
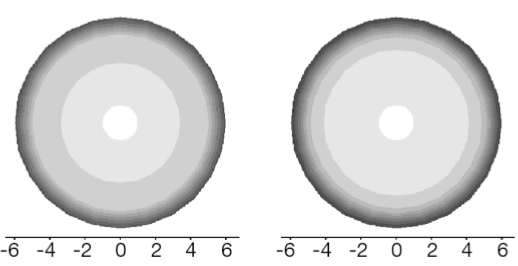
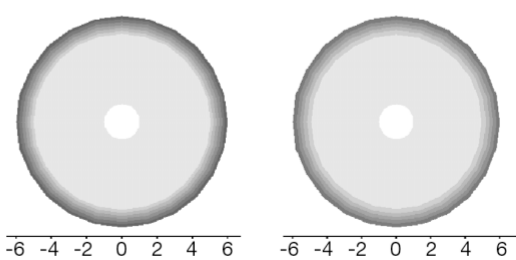

50
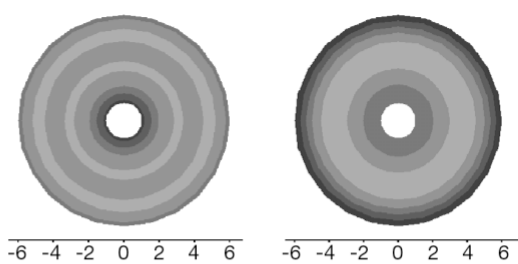

\begin{tabular}{lllllll}
\hline$-\dot{6}$ & $-\dot{4}$ & $-\dot{2}$ & $\dot{0}$ & 2 & $\dot{4}$ & $\dot{6}$
\end{tabular}

\begin{tabular}{lllllll}
\hline-6 & $-\dot{4}$ & -2 & 0 & 2 & 4 & 6
\end{tabular}

0102030405060708090100

Fig. 7. Average number of settled larvae and inert particles in relation to water flow. The individual sieve scales represent coordinates where measurements were recorded, relative to the center of the screen $(0,0)$ in $\mathrm{cm}$. The center was not sampled

derma pinnulatum and Hiatella arctica, and the scallop Chlamys islandica). However, a multi-scale approach involving a hierarchical sampling strategy highlighted the importance of the sampling scale in investigating larval behavior and showed an active selection process of an attachment site at small scales of observation

Table 6. Summary of regression models between number of settlers and inert particles averaged by sampling cell position according to the water flow $(\mathrm{n}=6)$. Significant probabilities are in bold $(\mathrm{p}<0.05)$

\begin{tabular}{|clrrrccc|}
\hline \multirow{2}{*}{ Flow } & Source & df & SS & MS & $F$ & $\mathrm{p}$ & $\mathrm{R}^{2}$ \\
\hline \multirow{2}{*}{0} & Model & 1 & 0.07 & 0.07 & 1.90 & 0.240 & 0.322 \\
& Error & 4 & 0.15 & 0.04 & & & \\
& total & 5 & 0.22 & & & & \\
10 & Model & 1 & 1.02 & 1.02 & 4.18 & 0.110 & 0.511 \\
& Error & 4 & 0.97 & 0.24 & & & \\
& total & 5 & 1.99 & & & & \\
20 & Model & 1 & 3.27 & 3.27 & 1.60 & 0.275 & 0.285 \\
& Error & 4 & 8.20 & 2.05 & & & \\
& Total & 5 & 11.48 & & & & \\
30 & Model & 1 & 0.53 & 0.53 & 0.29 & 0.617 & 0.068 \\
& Error & 4 & 7.21 & 1.80 & & & \\
& total & 5 & 7.74 & & & & \\
40 & Model & 1 & 0.22 & 0.22 & 0.05 & 0.832 & 0.013 \\
& Error & 4 & 17.30 & 4.32 & & & \\
& Total & 5 & 17.52 & & & & \\
50 & Model & 1 & 17.95 & 17.95 & 7.95 & $\mathbf{0 . 0 4 8}$ & $\mathbf{0 . 6 6 5}$ \\
& Error & 4 & 9.03 & 2.26 & & & \\
& Total & 5 & 26.98 & & & & \\
\hline
\end{tabular}

( $\mu \mathrm{m}$ to $\mathrm{mm}$ ) for bivalve mollusks (Harvey \& Bourget 1997, Bourget \& Harvey 1998). Similarly, the relationship between larval supply and settlement is variable at the scale of cm (Mullineaux \& Butman 1991, Mullineaux \& Garland 1993). In our experiments, active settlement behavior in relation with hydrodynamics appeared at the scale of $\mathrm{cm}$.

For water flow of $50 \mathrm{l} \mathrm{h}^{-1}$ (velocity $>3.9 \mathrm{~cm} \mathrm{~s}^{-1}$ ), the settlement pattern was significantly correlated with the pattern of inert particles. The settlement pattern of Mytilus spp. larvae was apparently fully under behavioral control at current velocities below $3.9 \mathrm{~cm} \mathrm{~s}^{-1}$. A recent study reports that at low free-stream velocity, the larvae of the red abalone Haliotis rufescens responded to a chemical settlement cue, whereas at higher free-stream velocity, the larvae lost their selectivity, increasingly behaving like passive particles (Boxshall 2000). Boxshall suggests that it was likely due to the inability of $H$. rufescens larvae to locate the inducer. Thus, as expected, active selection appears to be directly related to water flow velocity. One might expect this to be related to the swimming capability or ability of the larva to maintain itself in the boundary layer during exploration.

The correlation between settlement and inert particle patterns (passive behavior) at the highest flow speed explained $66.7 \%$ of the variance. Limited active selection behavior or desertion of unfavorable sites would likely explain much of the other part of the variance (Abelson \& Denny 1997). Video image analysis of 
$\begin{array}{lllll}\text { Flow }\left(1 h^{-1}\right) 10 & 20 & 30 & 40 & 50\end{array}$
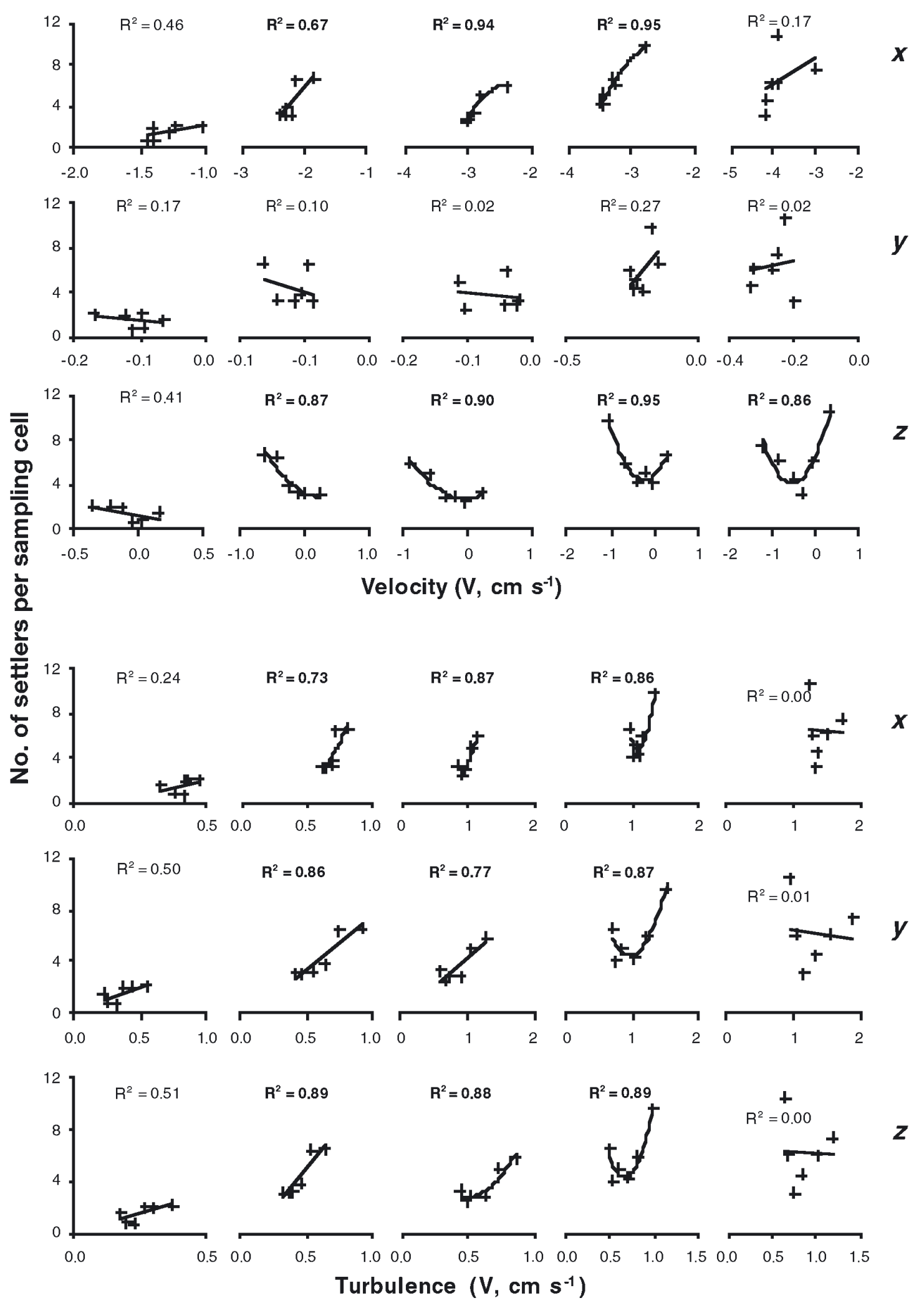

Fig. 8. Relationship between number of settled larvae, and velocity $(\mathrm{V})$ and turbulence $(\Delta \mathrm{V})$. Total velocity $\left(\mathrm{V}_{\Sigma}\right)$ and turbulence $\left(\Delta \mathrm{V}_{\Sigma}\right)$ were measured along the $x^{-}, y_{\text {- }}$ and $z$-axes. Significant regressions are in bold $(\mathrm{p}<0.05)$ 

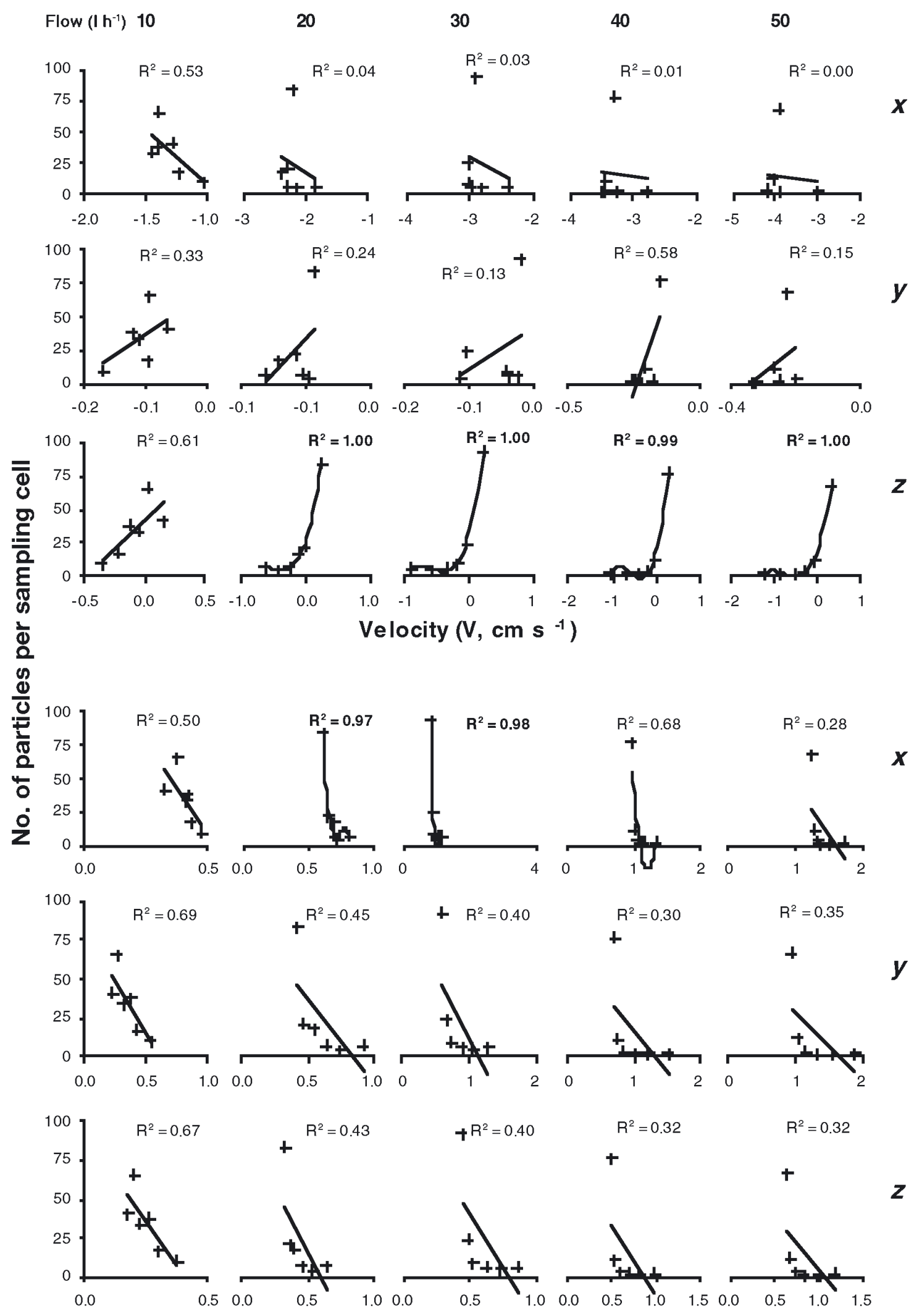

\section{Turbulence (V, $\left.\mathrm{cm} \mathrm{s}^{-1}\right)$}

Fig. 9. Relationship between number of inert particles, and velocity $(\mathrm{V})$ and turbulence $(\Delta V)$. See Fig. 8 for details 


\section{Day after fertilization}
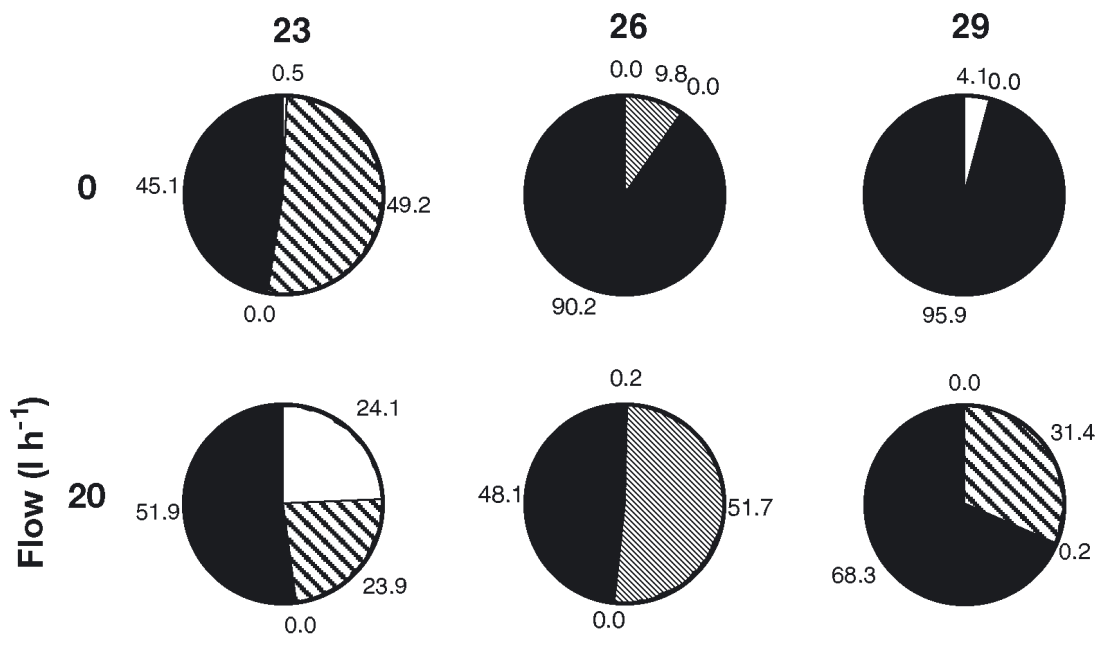

50
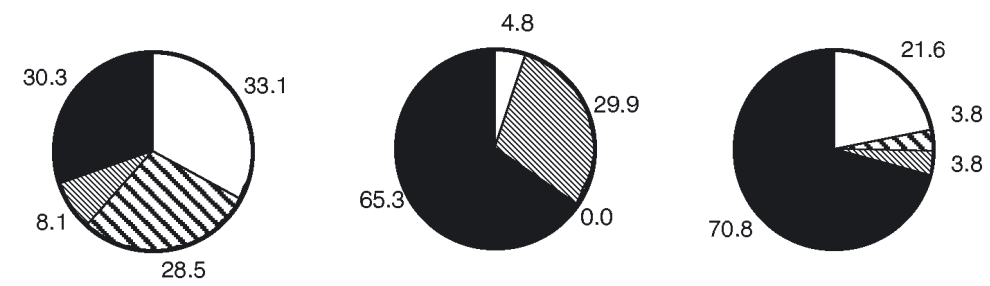

Fig. 10. Activity time budgets for mussel larvae according to water flow and time. Recorded behavior were: larvae actively crawling $(\square)$, remaining fixed on the screen $(\boldsymbol{\square})$, swimming $(\boldsymbol{\nabla})$ or passive in the water column $(\mathbb{Q})$. Sections of each pie

chart represent the mean proportion of time each behavior was observed rather than die without settling; this theory is based on the 'desperate larva hypothesis' (Toonen \& Pawlik 1994). However, at the end of our experiment (Day 29), larvae in the $501 \mathrm{~h}^{-1}$ cylinders spent $22 \%$ of the observation time actively exploring the substratum, thus suggesting that they had not lost their selectivity. Similarly, recent studies showed that larvae of the gregarious tubeworm Hydroides dianthus do not exhibit decreased substratumspecificity during the settlement period (Toonen \& Pawlik 2001a,b). Therefore, it seems that the desperate larva hypothesis is species specific. Another explanation would be that the high exploration behavior at the end of experiment reflects the post-settlement dispersal process, since some individuals were drifting with byssal threads (F. Pernet pers. obs.). Postsettlement active dispersal has been shown in many bivalve species including mussels (Bayne 1964, Martel \& Chia 1991, Harvey et al. 1995b, Hewitt et al. 1997, Norkko et al. 2001, Hunt \& Mullineaux 2002). larval behavior revealed that active exploration of the substratum occurred in the $50 \mathrm{l} \mathrm{h}^{-1}$ water flow treatment. In summary, 1 of the 6 water flows investigated in this study was above the threshold of active selection by larvae.

Active larval exploration of the substrate seemed to increase with water flow at the beginning of the experiment period. Mussel larvae spent $50 \%$ of the observation time swimming in the water column in still water conditions compared to 24 to $28 \%$ in moving water. Such swimming activity in competent larvae was previously reported for the bryozoan Bugula neritina (up to $45 \%$ of observation time) and was assumed to be associated with the lack of flow (Walters et al. 1999). Our results suggest that water flow influences positively the time allocated to active exploration of the larvae at the expense of swimming activity. Behavioral analysis also revealed that the exploration time of the larvae becomes nearly 0 in the middle of the settlement period (Day 26). Thus, larvae possibly lost their selectivity with age as observed with the barnacle Balanus amphitrite (Rittschof et al. 1984, Pechenik et al. 1993, Qian \& Pechenik 1998, Miron et al. 1999). It has been suggested that larvae become less discriminating as they age, because they risk settlement in a poor site

\section{Application of the experimental nursery}

This experimental nursery permits us to investigate the spatial distribution and behavior of settlers in response to water flow as well as to measure larval survival and settlement success in relation to the hydrodynamic regime. Usually, in flume or pipe experiments, the area of study represents a fraction of the experimental unit and this does not allow quantitative measurement of survival and settlement success. The experimental nursery system also offers the possibility to apply a wide range of treatments and replicates, whereas most of the flume experiments have to deal with pseudoreplication in time or space. Finally, results are directly applicable to commercial hatcheries given the similarity of the cylindrical sieve design and the orientation of the water flow used by growers.

However, limitations have also been found. For instance, it appeared difficult to isolate the effect of a particulate hydrodynamic variable, because one simultaneously varied with another. From our experience, it is possible to partially circumvent this problem and to investigate the effect of turbulence without altering velocity by changing the mesh size of the 
screen. In fact, when mesh size increased from 132 to $151 \mu \mathrm{m}$, overall turbulence decreased significantly without changing the velocity profile (F. Pernet unpubl. data).

Acknowledgements. The authors thank E.-J. Arsenault for her assistance in the culture of larvae and microalgae, and R. Boudreau, C. Rochefort, J. Fournier and J. Beaudin of CAMGR (Centre Aquacole Marin de Grande-Rivière) of MAPAQ (Ministère de l'Agriculture des Pêches et de l'Alimentation du Québec) for their assistance in the construction of the experimental nursery. We are grateful to T. Fandeur from Ecole des Mines de Douai (France) for his involvement in the project. Thanks are due to Dr. B. A. MacDonald from the University of New Brunswick for lending us his endoscope camera. Thanks are also given to G. Daigle, Département de mathématique et statistique, Université Laval, Quebec for validating the statistical analysis. Funding for this research has been provided by CORPAQ (Conseil des Recherches en Pêche et en Agro-alimentaire du Québec), MAPAQ and GIROQ (Groupe interuniversitaire de recherches océanographiques du Québec).

\section{LITERATURE CITED}

Abelson A, Denny MW (1997) Settlement of marine organisms in flow. Annu Rev Ecol Syst 28:317-339

Baker SM, Mann R (1994) Feeding ability during settlement and metamorphosis in the oyster Crassostrea virginica (Gmelin, 1791) and the effects of hypoxia on post-settlement ingestion rates. J Exp Mar Biol Ecol 181:239-253

Bayne BL (1964) Primary and secondary settlement in Mytilus edulis L. (Mollusca). J Anim Ecol 33:513-523

Bourget E, Harvey M (1998) Spatial analysis of recruitment of marine invertebrates on arborescent substrata. Biofouling 12:45-55

Boxshall A (2000) The importance of flow and settlement cues to larvae of the abalone, Haliotis rufescens Swainson. J Exp Mar Biol Ecol 254:143-167

Butman CA (1987) Larval settlement of soft-sediment invertebrates: the spatial scales of pattern explained by active habitat selection and the emerging role of hydrodynamical processes. Oceanogr Mar Biol Annu Rev 25:113-165

Butman CA (1989) Sediment-trap experiments on the importance of hydrodynamical processes in distributing settling invertebrate larvae in near-bottom waters. J Exp Mar Biol Ecol 134:37-88

Crimaldi J, Thompson J, Rosman J, Lowe R, Koseff J (2002) Hydrodynamics of larval settlement: the influence of turbulent stress events at potential recruitment sites. Limnol Oceanogr 47:1137-1151

Denny MW (1988) Biology and the mechanics of the waveswept environment. Princeton University Press, Princeton, NJ

Eckman JE (1983) Hydrodynamic processes affecting benthic recruitment. Limnol Oceanogr 28:241-257

Eckman JE, Duggins DO (1998) Larval settlement in turbulent pipe flows. J Mar Res 56:1285-1312

Fréchette M, Butman CA, Geyer WR (1989) The importance of boundary-layer flows in supplying phytoplankton to the benthic suspension feeder, Mytilus edulis L. Limnol Oceanogr 34:19-36

Gallager SM (1993) Hydrodynamic disturbances produced by small zooplankton: case study for the veliger larva of a bivalve mollusc. J Plankton Res 15:1277-1296
Hannan CA (1984) Planktonic larvae may act like passive particles in turbulent near-bottom flows. Limnol Oceanogr 29:1108-1116

Harvey M, Bourget E (1997) Recruitment of marine invertebrates onto arborescent epibenthic structures: active and passive processes acting at different spatial scales. Mar Ecol Prog Ser 153:203-215

Harvey M, Bourget E, Ingram RG (1995a) Experimental evidence of passive accumulation of marine bivalve larvae on filamentous epibenthic structures. Limnol Oceanogr 40: 94-104

Harvey M, Miron G, Bourget E (1995b) Resettlement of Iceland scallop (Chlamys islandica) spat on dead hydroids: response to chemical cues from the protein-chitinous perisarc and associated microbial film. J Shellfish Res 14: 383-388

Hewitt JE, Pridmore RD, Thrush SF, Cummings VJ (1997) Assessing the short-term stability of spatial patterns of macrobenthos in a dynamic estuarine system. Limnol Oceanogr 42:282-288

Holland DL, Spencer BE (1973) Biochemical changes in fed and starved oysters, Ostrea edulis L. during larval development, metamorphosis and early spat growth. J Mar Biol Assoc UK 53:287-298

Hunt HL, Mullineaux LS (2002) The roles of predation and postlarval transport in recruitment of the soft shell clam (Mya arenaria). Limnol Oceanogr 47:151-164

Legendre P, Legendre L (1998) Numerical ecology. Elsevier, Amsterdam

Lindegarth M, Jonsson P, Andre C (2002) Physical and numerical modeling of the role of hydrodynamic processes on adult-larval interactions of a suspension-feeding bivalve. J Mar Res 60:499-516

Mackenzie BR, Leggett WC (1991) Quantifying the contribution of small-scale turbulence to the encounter rates between larval fish and their zooplankton prey: effects of wind and tide. Mar Ecol Prog Ser 73:149-160

Martel A, Chia FS (1991) Drifting and dispersal of small bivalves and gastropods with direct development. J Exp Mar Biol Ecol 150:131-147

Miron G, Bourget E, Archambault P (1996) Scale of observation and distribution of adult conspecifics: their influence in assessing passive and active settlement mechanisms in the barnacle Balanus crenatus (Brugiere). J Exp Mar Biol Ecol 201:137-158

Miron G, Boudreau B, Bourget E (1999) Intertidal barnacle distribution: a case study using multiple working hypotheses. Mar Ecol Prog Ser 189:205-219

Mullineaux LS, Butman CA (1990) Recruitment of encrusting benthic invertebrates in boundary-layer flows: a deep water experiment on Cross Seamount. Limnol Oceanogr 35:409-423

Mullineaux LS, Butman CA (1991) Initial contact, exploration and attachment of barnacle (Balanus amphitrite) cyprids settling in flow. Mar Biol 110:93-103

Mullineaux LS, Garland ED (1993) Larval recruitment in response to manipulated field flows. Mar Biol 116:667-683

Norkko A, Cummings VJ, Thrush SF, Hewitt JE, Hume T (2001) Local dispersal of juvenile bivalves: implications for sandflat ecology. Mar Ecol Prog Ser 212:131-144

Pawlik JR, Butman CA (1993) Settlement of a marine tube worm as a function of current velocity: interacting effects of hydrodynamics and behavior. Limnol Oceanogr 38: $1730-1740$

Pawlik JR, Butman CA, Starczak VR (1991) Hydrodynamic facilitation of gregarious settlement of a reef-building tube worm. Science 251:421-424 
Pearce CM, Bourget E (1996) Settlement of larvae of the giant scallop, Placopecten magellanicus (Gmelin), on various artificial and natural substrata under hatchery-type conditions. Aquaculture 141:201-221

Pechenik JA, Rittschof D, Schmidt AR (1993) Influence of delayed metamorphosis on survival and growth of juvenile barnacles Balanus amphitrite. Mar Biol 115:287-294

Pernet F, Tremblay R, Langdon C, Bourget E (in press) Effect of additions of dietary triglyceride microspheres on growth, survival and settlement of mussel (Mytilus sp.) larvae. Mar Biol

Qian PY, Pechenik JA (1998) Effects of larval starvation and delayed metamorphosis on juvenile survival and growth of the tube-dwelling polychaete Hydroides elegans (Haswell). J Exp Mar Biol Ecol 227:169-185

Qian P, Rittschof D, Sreedhar B, Chia F (1999) Macrofouling in unidirectional flow: miniature pipes as experimental models for studying the effects of hydrodynamics on invertebrate larval settlement. Mar Ecol Prog Ser 191:141-151

Qiu JW, Tremblay R, Bourget E (2002) Ontogenetic changes in hyposaline tolerance in the mussels Mytilus edulis and M. trossulus: implications for distribution. Mar Ecol Prog Ser 228:143-152

Rittschof D, Branscomb ES, Costlow JD (1984) Settlement and behavior in relation to flow and surface in larval barnacles, Balanus amphitrite Darwin. J Exp Mar Biol Ecol 82:131-146

Rothschild BJ, Osborn TR (1988) Small-scale turbulence and plankton contact rates. J Plankton Res 10:465-474

Sherrer B (1984) Biostatistique. Gaëtan Morin, Montréal

Snelgrove PVR (1994) Hydrodynamic enhancement of invertebrate larval settlement in microdepositional environments: colonization tray experiments in a muddy habitat. J Exp Mar Biol Ecol 176:149-166

Editorial responsibility: Otto Kinne (Editor), Oldendorf/Luhe, Germany
Snelgrove PVR, Grassle JP, Grassle JF, Petrecca RF, Ma H (1999) In situ habitat selection by settling larvae of marine soft-sediment invertebrates. Limnol Oceanogr 44: 1341-1347

Tabachnik BG, Fidell LS (2001) Using multivariate statistics. Allyn \& Bacon, Boston

Toonen RJ, Pawlik JR (1994) Foundation of gregariousness. Nature 370:511-512

Toonen RJ, Pawlik JR (1996) Settlement of the tube worm Hydroides dianthus (Polychaeta: Serpulidae): cues for gregarious settlement. Mar Biol 126:725-733

Toonen RJ, Pawlik JR (2001a) Settlement of the gregarious tube worm Hydroides dianthus (Polychaeta: Serpulidae). 1. Gregarious and nongregarious settlement. Mar Ecol Prog Ser 224:103-114

Toonen RJ, Pawlik JR (2001b) Settlement of the gregarious tube worm Hydroides dianthus (Polychaeta: Serpulidae). 2. Testing the desperate larva hypothesis. Mar Ecol Prog Ser 224:115-131

Vogel S (1994) Life in moving fluids: the physical biology of flow. W. Grant Press, Boston

Walters LJ, Hadfield MG, Del Carmen KA (1997) The importance of larval choice and hydrodynamics in creating aggregations of Hydroides elegans (Polychaeta: Serpulidae). Invertebr Biol 116:102-114

Walters L, Miron G, Bourget E (1999) Endoscopic observations of invertebrate larval substratum exploration and settlement. Mar Ecol Prog Ser 182:95-108

Woodin SA (1986) Settlement of infauna: larval choice? Bull Mar Sci 39:401-407

Wright J, Boxshall A (1999) The influence of small-scale flow and chemical cues on the settlement of two congeneric barnacle species. Mar Ecol Prog Ser 183:179-187

Submitted: March 24, 2003; Accepted: June 14, 2003

Proofs received from author(s): September 23, 2003 